\title{
Müzik Öğretmenliği Lisans Öğrencilerinin Çalgı Sınavındaki Performans Kaygı Düzeylerinin Çeşitli Değişkenlere Göre İncelenmesi
}

\author{
Doç. Dr. Mehmet Serkan Umuzdaş ${ }^{*}$ \\ Hatice Tök ${ }^{2}$
}

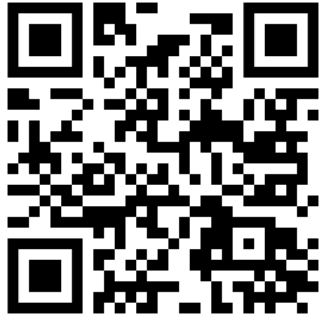

Geliş tarihi: 21.09 .2020

Kabul tarihi: 18.11.2020

\section{Atıf bilgisi:}

IBAD Sosyal Bilimler Dergisi

Sayı: Özel Sayı Sayfa: 396-410

Yıl: 2020

This article was checked by iThenticate. Similarity Index 23\%

Bu makalede araştırma ve yayın etiğine uyulmuştur.

Tokat Gaziosmanpaşa Üniversitesi, Türkiye,sumuzdas@yahoo.com ORCID ID 0000-0002-5455-2770

2 Tokat Gaziosmanpaşa Üniversitesi, Türkiye, haticetok19@hotmail.com ORCID ID 0000-0001-7251-5722

* Sorumlu yazar
ÖZ

$\mathrm{Bu}$ araştırma, müzik öğretmenliği lisans programında çalg1 eğitimi almakta olan öğrencilerin Sürekli-Durumluk Kaygı Düzeyleri’nin cinsiyet, yaş, sınıf düzeyi, çalgı farklılığı, mezun olduğu lise ve okumuş oldukları üniversite değişkenlerine göre durum tespiti yapmak amacıyla yapılmıştır. Araştırmada nicel betimsel yöntem benimsenmiştir. Çalışma, 2019-2020 güz yarıyılında öğrenim görmekte olan Abant İzzet Baysal Üniversitesi, Ondokuz Mayıs Üniversitesi, Karadeniz Teknik Üniversitesi ve Tokat Gaziosmanpaşa Üniversitesi Eğitim Fakültesi Güzel Sanatlar Eğitimi Bölümü Müzik Eğitimi Anabilim Dalı lisans öğrencileri $(\mathrm{N}=341)$ ile yürütülmüştür. Araştırma verilerinde, Spielberg vd. (1964) tarafindan geliştirilmiş olan, Öner ve Le Compte (1983)' nin Türkçe'ye uyarladığı "Sürekli-Durumluk Kaygı Envanteri" kullanılmıştır. Bu araştırmada Envanterin Cronbach Alpha güvenirlik katsayısı $\alpha=0,92$, KMO analizi sonucu 0,960 , Barlett's testi sonucu 6464,957 olarak saptanmıştır. Her iki analiz sonucunda $\mathrm{p}=0,000$ önem düzeyinde anlamlı bulunmuștur. Verilerin analizi için SPSS 22.0 paket programından yararlanılmıştır. Çalışmada belirlenen değişkenler bakımından müzik öğretmenliği lisans öğrencilerinin yaş, sınıf, çalgı ve üniversite değişkenlerine göre SDK düzeylerini belirlemede gruplararası iki faktörün bağımlı değişken üzerindeki etkisini ayrı ayrı test etmek yerine, faktörlerin temel etkilerini ve iki faktörün bağımlı değişken üzerindeki ortak etkisini eş zamanlı olarak test etmek için "Anova" testi kullanılmıştır. Cinsiyet ve mezun olduğu lise değişkenine göre SDK düzeylerini belirlemede ise tek faktörlü gruplar arası desenler için iki ilișkisiz örneklem ortalamaları arasındaki farkın anlamlı olup olmadığını test etmek için "bağımsız t" testi kullanılmıştır. Araştırmada elde edilen bulgulara göre, sürekli ve durumluk kaygı arasında anlamlı bir fark görülmüştür. Müzik öğretmenliği lisans öğrencilerinin sürekli ve durumluk kaygıları cinsiyet, yaş ve sınıfa göre anlamlı bir farklılık göstermektedir. Çalgı farklılığı ise sürekli kaygı durumunda anlamlı çıkmıştır. Mezun olunan lise ve okumuş oldukları üniversite değişkenine göre ise anlamlı bir farklılık görülmemiştir.

Anahtar Kelimeler: Çalgı sınavı, kaygı, öğrenci, performans kaygısı, müzik eğitimi 


\title{
An Examination of The Performance Anxiety Levels of Undergraduate Music Teaching Students in The Instrument Exams According to Various Variables
}

\author{
Assoc. Prof. Dr. Mehmet Serkan Umuzdaş ${ }^{*}$ \\ Hatice Tök ${ }^{2}$
}

First received: 21.09 .2020

Accepted: 18.11 .2020

\section{Citation:}

IBAD Journal of Social Sciences Issue: Special Issue Pages: $396-410$ Year: 2020

This article was checked by iThenticate. Similarity Index 23\%

1 Tokat Gaziosmanpaşa University, Turkey, sumuzdas@yahoo.com ORCID ID 0000-0002-5455-2770

.

2 Tokat Gaziosmanpaşa University, Turkey, haticetok19@hotmail.com ORCID ID 0000-0000-0000-0000

\footnotetext{
* Corresponding Author
}

\begin{abstract}
Quantitative descriptive method has been adopted in order to analyze the trait-state anxiety levels of students who are studying instrument in the Music Teaching Undergraduate Program according to gender, age, grade level, instrument difference, high school they graduate and the university they studied. The study was conducted with undergraduate students $(\mathrm{N}=341)$ of the Department of Music Education, Department of Fine Arts Education, Faculty of Education of the Black Sea region who are studying in the fall semester of 2019-2020. Data from the study Spielberg et al. The "continuous-state anxiety inventory" developed by Öner and Le Compte (1983), adapted to Turkish, was used. In this study, the Cronbach Alpha reliability coefficient of the Inventory was determined as $\alpha=0,92$, the KMO analysis result was 0,960 , and the Bartlett's test result was 6464,957. As a result of both analyzes, it was found to be significant at the $p=0.000$ significance level. SPSS 22.0 package program was used for data analysis. In determining the SDK levels according to age, grade, instrument and university variables, instead of testing the effect of two intergroup factors on the dependent variable separately, the "Anova" test was used to simultaneously test the main effects of the factors and the joint effect of the two factors on the dependent variable. In determining the SDK levels according to the variable of gender and graduated high school, "independent $t "$ test was used to test whether the difference between two unrelated sample averages was significant for designs between groups with one factor.The continuous anxiety inventory was conducted at a time when the students were away from the stress of the exam, and the status anxiety inventory was conducted just before the final exam.According to the findings of the study, there was a significant difference between persistent and situational anxiety. The continuous and situational concerns of music teacher students vary significantly according to gender, age and class. The difference in the instrument was significant in the case of constant anxiety. There was no significant difference between the graduated high school and the university they studied.
\end{abstract}

Keywords: Instrument exam, anxiety, student, performance anxiety, music education 


\section{GíRiş}

Kaygı, bir bireyin tehdit olarak algıladığı bir uyaranla maruz kaldığında yaşadığı bedensel, duygusal ve zihinsel değişimlerle birlikte ortaya çıkmakta olan bir tepki halidir. Bireyin kişiliğini ve davranışını incelemekte olan gerek biyolojik gerekse fizyolojik alanlardaki tüm kuramlarda çoğu zaman kaygıya da yer verilmiştir. Kimileri tarafından kaygı, bireyin kimliğini oluşturan temel bir güç olarak kabul edilmekte, kimileri tarafindan ise bireyin kimliğinin yapılanmasında ve tutumun ortaya konmasında önemli bir faktör olarak görülmektedir.

Kaygı kavramı bilimsel olarak 19. yüzyılda Freud tarafından ele alınmış bir kavramdır. Freud' tan önce kaygı, korku kavramı ileberaber ele alınmış olup Freud'un çalışmalarıyla birlikte kaygı korkudan ayrı bir kavram olarak tanımlanmıştır. Freud kaygıyı, bireyin tehlikeli bir durum esnasında etkili bir tutum sergileyememe ve bu durum karşısında direnememe sonucu bilinç dışı olarak meydana gelen duygu olarak açıklamıştır (Üldaş, 2005, s.7). Kaygı, bireyin tehdit karşısında hissettiği korku, stres ya da huzursuzluk hali olarak da tanımlanabilmektedir. (Büyüköztürk, 1997, s.453). Ayrıca kayg1, kapsamlı olarak bireyin sezilen bir tehlikeyle karşılaşması durumunda ortaya çıkan güçsüzlük hissinin sürdüğü duygusal bir durum olarak da açıklanabilmektedir.

Bireyin sürekli olarak huzursuzluk içinde yaşaması, çoğu kez mutsuz olması durumu da söz konusu olabilir. Sürekli kaygı, içten kaynaklanan, doğrudan dış tehditlerle ilişkisi olmayan bir kaygı türüdür. $\mathrm{Bu}$ durumda birey, benliğinin tehdit edildiğini algılar ya da içinde olduğu vaziyetleri stresli olarak yorumlar (Öner ve Le Compte, 1985, s.2).

Genellikle tehlikeli durumların ortaya çıkardığı korkunun ve tedirginliğgin, bireyin yaşamış olduğu normal ve geçici olduğu kabul edilmektedir. Bireyin bulunduğu duruma dolaylı olarak bağlı olabilen sürekli kaygı da kişilik özelliğini belirleyebilmektedir. Kişilik özelliği bireyin kaygıya olan eğiliminden etkilenebilir. Kaygılı birey, içinde olduğu durumları stresli olarak algılayabilir. Sürekli kaygı, olağan durumların bireyin benliği tehdit edici unsur algısıyla meydana gelen mutsuzluk duygusudur (Öner ve Le Compte, 1985, s.2). Yüksek sürekli kaygı düzeyine sahip bireylerde, kolaylıkla incinme ve olumsuz düşüncelere kapılma görülür. Bu bireyler durumluk kaygıyı diğer kişilere göre daha yoğun ve daha sık yaşarlar. Sürekli ve durumluk kaygı arasındaki etkileşimde görüldügüü üzere, müzisyenlerde de durumluk kaygıya bağlı olarak bir kaygı durumu ortaya çıkmış ve bu kaygı durumu MPK olarak nitelendirilebilmektedir.

Kayg1, bireyin temel duygularından biri olarak kabul edilir. Bireyin, kötü bir olayın var olması olasılığına ilişkin bir sıkıntı hissetmesi durumudur. $\mathrm{Bu}$ duygu, panik derecesine kadar farklı yoğunluklarda olabilir. Kaygı durumunda kan basıncının yükselmesi, kaslarda gerginlik, ağız kuruluğu, el ve ayaklarda terleme gibi fizyolojik belirtiler görülebilir. Tehlikeli durumların ortaya çıkardığ 1 bu kaygı türü çoğunlukla her bireyin başına gelebilen, geçici olarak bir duruma bağl1 olan duyguyu oluşturur. Bu 'durumluk kayg1"' olarak tanımlanır (Öner ve Le Compte, 1985, s.1).

Performans kaygısı ise, bireyin sergileyeceği performans hakkında negatif sonuçlar almaktan, eleştirilmekten, yeterince başarılı olamamaktan endişe duymasıdır. Le Blanc (akt. Alptekin, 2012)'a göre performans kaygısı yaş, sağlık ve yeterli hazırlanma süresi, izleyici sayısı, ezberin iyi olması, seyircilerin bilgi düzeyi, sanatçının onlara atfettiği önem, ses/görüntü kayıt araçlarının kullanılması gibi faktörlerden etkilenmektedir. Performans kaygısı, kişide fizyolojik (nefes darlığı, kalp çarpıntısı, ağız kuruluğu, mide bulantısı, titreme, soğuk eller, aşırı tuvalet ihtiyacı), bilişsel (özgüven kaybı, performans hakkındaki düşünceler, hatırlama problemleri, hata yapma korkusu, dikkat ve denge kaybı, hatanın sonuçlarına dair çıkarımlar, statü kaybı öngörüsü, performanstan kopma korkusu) ve davranışsal (güçsüzlük, sesin titremesi, çevreye karşı agresif tavırlar, gergin ve kalkık omuzlar, sosyal ilişkilerde bozulma) belirtilerle hazırlık ve performans sırasında kendini gösterir (akt. Tokinan, 2013). Cox ve Kenardy (1993, s.53), performans kaygısını bireyin başka insanlar önünde motor becerilerini kontrol edememe veya bir hata yapma korkusuyla ilişkili olarak meydana gelen kaygı durumu olarak tanımlamıştır. Performans kaygısı ile baş etmenin davranışsal boyutuna bakıldığında ise bireyler, bu kaygının üstesinden gelmek yerine pekte işlevli olmayan davranış durumları sergilemektedir. Birey kaygının üstesinden gelemeyeceğini düşündüğ̈̈nde kaygı hissi uyandıran tüm durumlardan kaçmak ya da kaçınmak isteyebilmektedir. Eğer 
birey tüm kaçma ya da kaçınma davranışlarına rağmen göstereceği performanstan uzaklaşamıyorsa kendine göre tedbirler alıp o performansı göstermeye çabalayabilir.

Performans sergileme denildiğinde akla ilk gelen meslek gruplarından biri de müzisyenlerdir. Gerek sahnede gerekse sınavlarda bu performans sergileme süreci onlar için kaçınılmaz bir hal almaktadır. Performans kaygısı, amatör müzisyenlerden profesyonel müzisyenlere kadar müzikle uğraşan (solistler, orkestra ve opera müzisyenleri vb.) geniş bir kitleyi etkisi altına alabilmektedir. Dolayısıyla müzik performansı, müzik çalışmaları sürecinin oldukça önemli bir parçası olarak kabul edilmektedir. Birçok çalışmada bu problemin varlığı kesin bir şekilde ele alınırken, performans sergileyen müzisyenler de yaşanılan zorlukların en önemli nedeninin Müzik Performans Kaygısı (MPK) olduğunu belirtilmektedir.

Müzik performansı bilişsel, duyuşsal, ve fizyolojik boyutları olan duygusal ve davranışsal bir yapıdır. Bir topluluk karşısında ve bir amaç doğrultusunda performansın gerçekleşmesini ve bu performansın sosyal ve bilişsel yönünü ortaya koymaktadır. Performansın içerdiği çeşitli durumların performans sırasında veya öncesinde ortaya çıkan kaygı ve çeşitli bileşenleri ile ilişkili olduğu görülmektedir. Çalgı eğitimi almakta olan her öğrenci bireysel çalgı final sınavlarında ya da sahnede performans sergilerken kaygı yaşamaktadır. Sınav esnasında öğrenci, bir komisyon tarafından değerlendirileceğini düşündüğü için performans esnasında istediği performansı sergileyemez hale gelebilmekte ve bu durumdan oldukça yakınabilmektedir. Sahne performansında değerlendirilme kaygısı olmasa da dinleyiciler tarafından beğenilmeme korkusu, düşüncelerini etkisi altına almaktadır. Öğrenciler, bireysel çalgı performansını devinişsel olarak sergileyeceğini düşündügünden performanslarını sergilediğinde başkaları tarafından izlenmek ve yanlış yapma korkusu, beğenilmeme vb. gibi nedenlerle paniğe kapılabilmekte ve kaygının yarattığı zihinsel, bedensel, duygusal ve tepkisel belirtilerini gösterebilmektedirler. $\mathrm{Bu}$ belirtilerin arasında, el ve ayaklarda terleme veya titreme, kalp atımının hızlanması, ağız kuruluğu vb. belirtiler sıralanabilir. Sonuç olarak performans, her müzisyenin hayatında olan önemli bir parçadır ve müzik, bireyin hayatında olduğu sürece performansını sergileyeceği ortamlar da hayatının merkezinde olacaktır.

Müzik performansının sergilenmesi amatör ya da profesyonel olarak eğitim alan veya almakta olan her bir bireyin hayatında nadiren ya da sıklıkla karşılaşmakta olduğu bir durumdur. MPK ise sergilenecek olan performans sırasında ya da öncesinde karşılaşılan bir durumdur. Kaygının belli bir düzeyde olması ve bireyin bir işi yapabilmesi için motivasyon sağlayan bir ortam yaratırken kaygının çok fazla olması durumunda birey, özellikle sahne ya da sinav performansı sırasında normal şartlarda rahatlıkla yapabileceği durumlarda bile bireyi zorlayıcı duruma sokabilmektedir. MPK' nın ortaya çıkışı, nedenleri ve kaygıyı hangi durumların ne şekilde etkilediğini anlamak, bireyin müzik eğitimi sürecinin başarılı bir şekilde devam ettirilebilmesi açısından büyük önem taşımaktadır.

Müzik eğitimi almakta olan öğrencilerin gerek sınavlarının gerekse konserlerde sergilediği performanslarının başarısızlıkla ya da istendik durum sergileyememe vb. sonuçlanması onları olumsuz etkileyebilmektedir. $\mathrm{Bu}$ araştırma ile müzik eğitimi bölümlerinde öğrenim görmekte olan lisans öğrencilerinin yaşamış oldukları kaygının çeşitli nedenleri ve kaygı durumunu tanımaları sağlanabilir. $\mathrm{Bu}$ kaygı durumu öğrencilerin bilişsel, duyuşsal, fizyolojik ve devinişsel alanlarında onlara yardımcı olabilir.

Buna göre araştırmanın amacı, müzik öğretmenliği lisans programında çalgı eğitimi almakta olan öğrencilerin çalg1 sınavı performans kaygılarını çeşitli değişkenlere göre incelemektir. Ayrıca sürekli kaygılarının da çalgı performans kaygısıyla ilişkilerini ortaya koymaktır. Bu amaçlar doğrultusunda müzik öğretmenliği lisans programında çalgı eğitimi almakta olan öğrencilerin, çalgı sınavı performans kaygıları çeşitli değişkenlere göre anlamlı farklılık göstermekte midir? sorusuna yanıt aranmıştır.

\section{Alt Problemler}

1. Müzik öğretmenliği lisans öğrencilerinin Sürekli-Durumluk Kaygı (SDK) puanları cinsiyete göre anlamlı farkl1l1k göstermekte midir?

2. Müzik öğretmenliği lisans öğrencilerinin SDK puanları yaşa göre anlamlı farklılık göstermekte midir?

3. Müzik öğretmenliği lisans öğrencilerinin SDK puanları sınıf düzeylerine göre anlamlı farklılık göstermekte midir?

IBAD Sosyal Bilimler Dergisi / IBAD Journal of Social Sciences, (Özel Sayı/Special Issue), 2020 
4. Müzik öğretmenliği lisans öğrencilerinin SDK puanları çalgıya göre anlamlı farklılık göstermekte midir?

5. Müzik öğretmenliği lisans öğrencilerinin SDK puanları mezun oldukları liseye göre anlamlı farklılık göstermekte midir?

6. Müzik öğretmenliği lisans öğrencilerinin SDK puanları okuduğu üniversiteye göre anlamlı farklılık göstermekte midir?

\section{YÖNTEM}

Müzik öğretmenliği lisans programında çalgı eğitimi almakta olan öğrencilerden elde edilen nicel verilerin işlendiği bu araştırma, lisans öğrencilerinin SDK düzeylerinin çeşitli değişkenlere göre farklılaşıp farklılaşmadığını belirlemek amacıyla betimsel tarama modelli bir çalışmadır. Öğrencilerin SDK düzeylerini belirlemek amacıyla Spielberger vd. (1964) tarafindan geliştirilen "Sürekli-Durumluk Kaygı Envanteri" kullanılmıştır. Bu envarterler, sürekli kaygı 20, durumluk kaygı 20 olmak üzere toplam 40 maddeden oluşmaktadır. 4'lü likert tipidir. Sürekli Kaygı Envanteri, bireyin içinde bulunduğu koşullardan bağımsız olarak kendini değerlendirmesi olarak kullanılır. Durumluk Kaygı Envateri ise, bireyin içinde bulunduğu duruma ait nasıl hissettiğini belirlemeye yarar. Envanterde ters ve düz ifadeler bulunmaktadır. Puanlama 20 ile 80 arasında değişmektedir.

\section{Çalışma Grubu}

Araştırmanın çalışma grubunu 2019-2020 güz yarıyılı Orta Karadeniz Bölgesi’nde Eğitim Fakültesi Güzel Sanatlar Eğitimi Bölümü Müzik Eğitimi Anabilim Dalı'nda çalgı eğitimi almakta olan (N=341) lisans öğrencileri oluşturmaktadır. Araştırmanın örneklemine göre Orta Karadeniz Bölgesi'nde beş üniversite bulunmaktadır fakat ülkemizi de etkisi altına alan Covid-19 salgını nedeniyle eğitim ve öğretime ara verilmesi durumunda Kastamonu Üniversitesine ait veriler araştırmacıya ulaşamamıştır.

Tablo 1'de çalışma grubunun değişkenlere göre dağılımları gösterilmektedir.

Tablo 1. Çalışma Grubunun Değişkenlere Göre Dă̆glımları

\begin{tabular}{|c|c|c|c|}
\hline \multicolumn{2}{|c|}{ Değişken } & \multirow{2}{*}{$\begin{array}{c}f \\
204\end{array}$} & \multirow{2}{*}{$\begin{array}{c}\% \\
59,82\end{array}$} \\
\hline Katılımcilar & $\mathrm{K} 1 \mathrm{z}$ & & \\
\hline & Erkek & 137 & 40,17 \\
\hline \multirow{4}{*}{ Yaş } & $18-21$ & 248 & 72,72 \\
\hline & $22-25$ & 82 & 20,04 \\
\hline & $26-29$ & 9 & 2,63 \\
\hline & $30-33$ & 2 & 0,58 \\
\hline \multirow{4}{*}{ Sinif } & Lisans 1 & 91 & 26,68 \\
\hline & Lisans 2 & 64 & 18,76 \\
\hline & Lisans 3 & 94 & 27,56 \\
\hline & Lisans 4 & 92 & 26,97 \\
\hline \multirow{13}{*}{ Çalg1 } & Keman & 83 & 24,34 \\
\hline & Viyola & 27 & 7,91 \\
\hline & Çello & 37 & 10,85 \\
\hline & Kontrbas & 1 & 0,29 \\
\hline & Flüt & 54 & 15,83 \\
\hline & Gitar & 49 & 14,36 \\
\hline & Bağlama & 34 & 9,97 \\
\hline & Piyano & 25 & 7,33 \\
\hline & Ud & 11 & 3,22 \\
\hline & Şan & 15 & 4,39 \\
\hline & Kanun & 3 & 0,87 \\
\hline & Klarnet & 1 & 0,29 \\
\hline & Ney & 1 & 0,29 \\
\hline
\end{tabular}


Müzik Öğretmenliği Lisans Öğrencilerinin Çalg1 Sınavındaki Performans Kayg1

Düzeylerinin Çeşitli Değişkenlere Göre İncelenmesi

\begin{tabular}{cccc}
\hline Mezun Olunan Lise & GSL & 238 & 69,79 \\
& Alan Diş1 & 101 & 26,61 \\
\hline & $\begin{array}{c}\text { Abant İzzet Baysal } \\
\text { Üniversitesi } \\
\text { Öniversite }\end{array}$ & 80 & 23,46 \\
& $\begin{array}{c}\text { Ondokuz Mayis } \\
\text { Üniversitesi } \\
\text { Karadeniz Teknik } \\
\text { Üniversitesi }\end{array}$ & 63 & 18,47 \\
& $\begin{array}{c}\text { Tokat Gaziosmanpaşa } \\
\text { Üniversitesi }\end{array}$ & 96 & 29,91 \\
& & 28,15 \\
\hline
\end{tabular}

\section{Veri Toplama Araçları}

Müzik Eğitimi Bölümü’nde çalgı eğitimi gören öğrencilerin SDK' larını belirlemek için "SürekliDurumluk Kaygı Envanteri” kullanılmıştır. Öğrencilerin SDK düzeylerini belirlemek amacıyla Spielberger vd. (1964) tarafından geliştirilen "Sürekli-Durumluk Kaygı Envanteri” kullanılmıştır.

\subsubsection{Sürekli-Durumluk Kaygı Envanteri}

Envanterin her biri 20 madde ve 4'lü likert tipinde olmak üzere iki ayrı ölçeği vardır. Sürekli kaygı envanteri; Birey içinde bulunduğu durum ve koşullardan bağımsız olarak kendini nasıl hissettiğini belirler. Durumluk kaygı envanteri; Bireyin belirli bir anda ve belirli koşullarda kendini nasıl hissettiğini belirler. (Spielberger vd. 1970)

Olumlu duyguları belirten ifadeler 4 puan, olumsuz duyguları belirten ifadeler ise 1 puan olacak şekilde puanlama yapılmıştır. SDK envanterinde düz ve ters ifadeler yer almaktadır. Olumlu duyguları belirten ters ifadelerde 1 değerindekiler 4, 4 değerindekiler ise 1' e dönüştürülmektedir. Olumsuz duyguları belirten düz ifadelerde 4 değerindeki cevaplar kaygının düzeyinin yüksekliğini göstermektedir. Ters ifadelerde ise 4 değerindekiler düşük, 1 değerindekiler de kaygı düzeyinin yüksek olduğu göstermektedir. İki envanterden elde edilen kaygı düzeyinin toplam puan değeri 20 ile 80 arasında değişmektedir. Puan ne kadar yüksek olursa yüksek kaygı düzeyini, ne kadar düşük olursa da düşük kaygı düzeyini belirtmektedir. Türkçe formun geçerlik ve güvenirliği ise Öner ve Le Compte tarafindan 1985 yılında yapılmıştır.

Kuder-Richardson 20 formülünün genelleştirilmiş bir formu olan alpha korelasyonları ile saptanan güvenirlik katsayılarının, Sürekli Kaygı Ölçeği için .83 ile .87 arasında; Durumluk Kaygı Ölçeği için .94 ile .96 arasında olduğu bulunmuştur. Bu elde edilen verilerde Türkçe ölçeklerin yüksek madde homojenliği ve iç tutarlılığa sahip olduğu görülmektedir. Her maddenin varyansıyla tüm ölçekten elde edilen puan varyansının ilişkisini arayan Item Remainder korelasyonu tekniği, ölçeği oluşturan maddelerin geçerliği ve güvenirliği hakkında ayrıntılı bir bilgi sağlar. Sürekli Kaygı Ölçeği için .34 ile .72; Durumluk Kaygı Ölçeği için ise; .42 ile .85 arasındadır. Ölçeğin test tekrar test yönteminden elde edilen güvenirlik katsayıları; Sürekli Kaygı Ölçeği için .71 ile .86 arasında; Durumluk Kaygı Ölçeği için .26 ile .68 arasında değiştiğini göstermektedir. SDK ölçeğinin Türkçeleştirilmesinde yapı ya da deneysel kavram geçerliği ve kriter geçerliği olmak üzere iki ayrı teknikte gerçekleştirilmiştir (Öner ve Le Compte, 1983, s.11).

$\mathrm{Bu}$ Araştırmada ise envanterin Cronbach Alpha güvenirlik katsayısı $\alpha=0,92, \mathrm{KMO}$ analizi sonucu 0,960, Barlett's testi sonucu 6464,957 olarak saptanmıştır. Her iki analiz sonucunda $p=0,000$ önem düzeyinde anlamlı bulunmuştur. Elde edilen güvenirlik katsayılarının oldukça yüksek olduğu; bir başka deyişle envanterin kaygıyı ölçmede yüksek derecede güvenilir ve güncel sonuçlar verdiği görülmüştür.

\section{Verilerin Toplanması}

Araştırma verileri Eğitim Fakültesi Güzel Sanatlar Eğitimi Bölümü Müzik Eğitimi Anabilim Dalı 20192020 güz yarıyılında öğrenim görmekte olan lisans öğrencilerine uygulanmıştır. Araştırmaya katılım sağlayan üniversite öğrencilerinin dağılımları şu şekildedir: Abant İzzet Baysal Üniversitesi’nden 80 kişi, Ondokuz Mayıs Üniversitesi'nden 63 kişi, Karadeniz Teknik Üniversitesi'nden 102 kişi, Tokat Gaziosmanpaşa Üniversitesi'nden ise 96 altı kişiye ulaşılmıştır. Envanterler gönüllü olan öğrencilere 
uygulanmıştır. Sürekli kaygı envanteri, öğrencilerin sınav stresinden uzak bir zaman diliminde uygulanmış olup durumluk kaygı envanteri ise final sınavından hemen önce uygulanmıştır.

\section{Verilerin Çözümlenmesi}

Araştırma verilerinin normal dağılıma uygunluğunu belirlemek amaciyla Kolmogorov-Smirnov normalite testi yapılmıştır. Analiz sonucunda elde edilen önem düzeyi 0,57 olarak belirlenmiștir. Verilerin analizinde, normal dağılımdan dolayı, parametrik testlerden olan t-testi ve tek yönlü varyans analizi (ANOVA) kullanılmıştır. Anlamlılık düzeyi 0,05 alınmıştır. Yaş, sınıf, çalgı ve üniversite değişkenlerine göre SDK düzeylerini belirlemede gruplararası iki faktörün bağımlı değişken üzerindeki etkisini ayrı ayrı test etmek yerine, faktörlerin temel etkilerini ve iki faktörün bağımlı değişken üzerindeki ortak etkisini eş zamanlı olarak test etmek için "Anova" testi kullanılmıştır. Cinsiyet ve mezun olduğu lise değişkenine göre SDK düzeylerini belirlemede ise tek faktörlü gruplar arası desenler için iki ilişkisiz örneklem ortalamaları arasındaki farkın anlamlı olup olmadığını test etmek için "bağımsız t" testi kullanılmıştır.

\section{BULGULAR}

Araştırmanın bu bölümünde araştırmanın amaçları doğrultusunda toplanan verilerden elde edilen bulgular, tablolaştırılarak verilmiş ve yorumları yapılmıştır. Müzik öğretmenliği lisans öğrencilerinin SDK' nın cinsiyete göre t-testi sonuçları Tablo 2' de gösterilmiştir.

Tablo 2. SDK Puanlarının Cinsiyete Göre T-Testi Sonuçları

\begin{tabular}{ccccccc}
\hline & $\mathrm{N}$ & $\begin{array}{c}\text { Ortalama } \\
(\overline{\mathrm{x}})\end{array}$ & $\begin{array}{c}\text { Standart } \\
\text { Sapma }(\sigma)\end{array}$ & sd & $\mathrm{t}$ & $\mathrm{p}$ \\
\hline Sürekli Kayg1 & & & & & & \\
\hline K1z & 204 & 44,87 & 8,77 & 339 & 3,21 &, 001 \\
Erkek & 137 & 41,81 & 8,41 & & & \\
\hline Durumluk & & & & & & \\
Kayg1 & & & & & & \\
\hline K1z & 204 & 45,25 & 11,49 & 339 & 3,07 & \\
Erkek & 137 & 41,45 & 10,61 & & & \\
\hline
\end{tabular}

Müzik öğretmenliği öğrencilerinin SDK' ları cinsiyete göre anlamlı bir farklılık göstermektedir. Sürekli kayg1 $\mathrm{t}_{(339)}=3.21, \mathrm{p}<.01$. Durumluk kayg1 $\mathrm{t}_{(339)}=3.07, \mathrm{p}<.01 . \mathrm{K} 1 \mathrm{z}$ ve erkeklerin SDK düzeylerinin durumunda yapılan bağımsız t testi sonucunda kız ve erkeklerin kaygı düzeylerinin birbirinden farklı olduğu görülmüştür. Sürekli kaygıya baktığımızda $\left(\mathrm{t}_{0,05: 75}=3,21\right)$ k1z öğrencilerin $(\overline{\mathrm{x}}=44,87)$ erkek öğrencilere $(\bar{x}=41,81)$ göre daha fazla kaygılandığı görülmüştür. Durumluk kaygıda $\left(t_{0,05: 75}=3,07\right)$ ise yine kız öğrencilerin $(\vec{x}=45,25)$ durumluk kaygı düzeyi erkek öğrencilere $(\bar{x}=41,45)$ göre daha yüksek olduğu görülmüştür.

Müzik öğretmenliği lisans öğrencilerinin SDK puanlarının yaşa göre ANOVA sonuçları Tablo 3'te verilmiştir.

Tablo 3. SDK Puanlarının Yaşa Göre ANOVA Sonuçları

\begin{tabular}{|c|c|c|c|c|c|c|c|c|c|}
\hline & \multicolumn{3}{|c|}{$f, \bar{x}$ ve ss Değerleri } & \multicolumn{5}{|c|}{ ANOVA Sonuçları } & \multirow[b]{2}{*}{$\mathrm{p}$} \\
\hline & $\mathrm{N}$ & $\overline{\mathrm{X}}$ & $\operatorname{SS}(\sigma)$ & Var. K. & $\mathrm{KT}$ & $\mathrm{Sd}$ & $\mathrm{KO}$ & $\mathrm{F}$ & \\
\hline Sürekli Kayg1 & & & & & & & & & \\
\hline $18-21$ & 248 & 44,46 & 8,85 & G. Aras 1 & 764,076 & 3 & 254,692 & 3,395 & ,018 \\
\hline $22-25$ & 82 & 41,13 & 8,30 & G. İçi & 25283,989 & 337 & 75,027 & & \\
\hline $26-29$ & 9 & 42,55 & 5,91 & Toplam & 26048,065 & 340 & & & \\
\hline $30-33$ & 2 & 49,50 & 6,36 & & & & & & \\
\hline
\end{tabular}




\begin{tabular}{cccccccccc}
\hline Durumluk Kayg1 & & & & & & & & & \\
$18-21$ & 248 & 44,92 & 11,14 & G. Aras1 & 1361,783 & 3 & 453,931 & 3,645 &, 013 \\
$22-25$ & 82 & 40,35 & 11,57 & G. İçi & 41973,844 & 337 & 124,551 & & \\
$26-29$ & 9 & 42,77 & 7,29 & Toplam & 43335,636 & 340 & & & \\
$30-33$ & 2 & 38,00 & 4,24 & & & & & & \\
\hline
\end{tabular}

Analiz sonuçları, müzik öğretmenliği öğrencilerinin SDK düzeyleri arasında yaş bakımından anlamlı bir

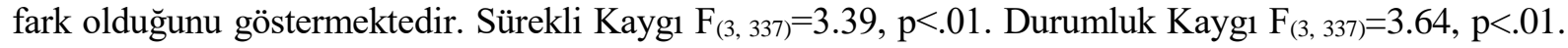
Bulgulara göre farkın kaynağı 18-21 ve 22-25 yaş aralığında olan öğrenciler olarak görülmektedir.

Müzik öğretmenliği lisans öğrencilerinin SDK puanlarının sınıf düzeyine göre ANOVA sonuçları Tablo 4'te verilmiştir.

Tablo 4. SDK Puanlarının Sinıf Düzeyine Göre ANOVA Sonuçları

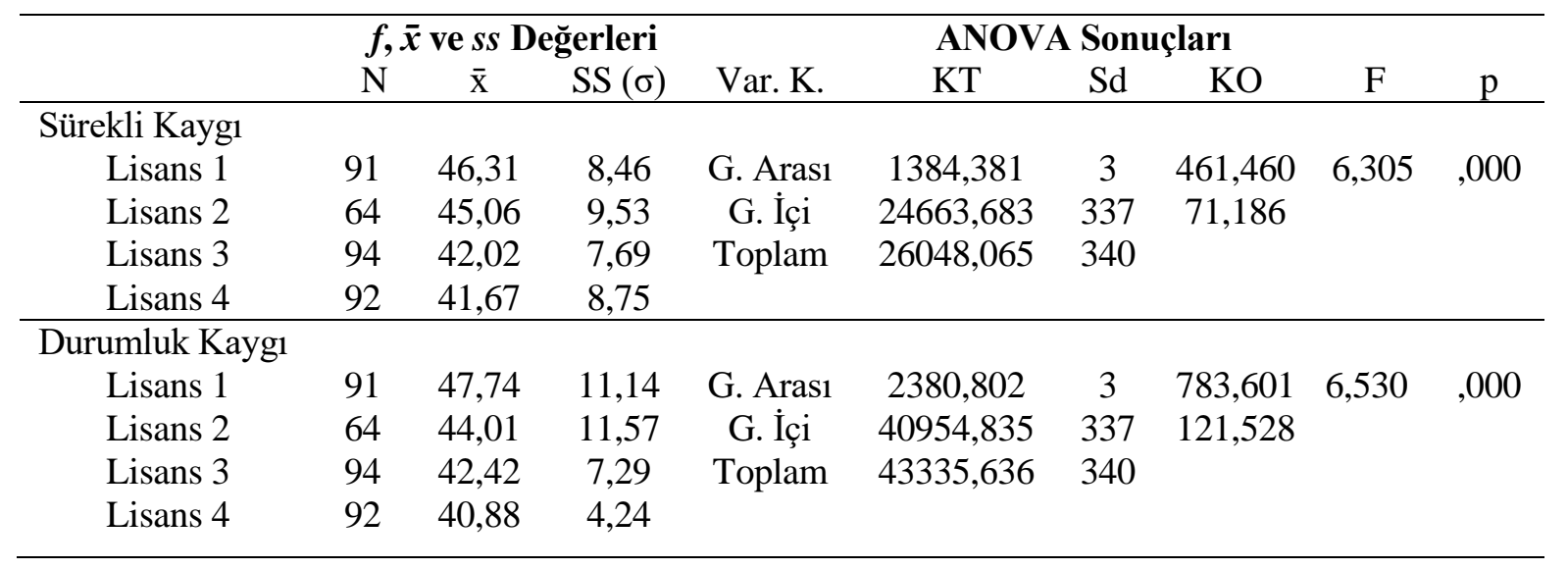

Analiz sonuçları, müzik öğretmenliği öğrencilerinin SDK düzeyleri arasında sınıf bakımından anlamlı bir fark olduğunu göstermektedir. Sürekli Kayg1 $F_{(3,337)}=6,30, p<.01$. Durumluk Kayg1 $F_{(3,337)}=6.53$, $\mathrm{p}<.01$. Bulgulara göre farkın kaynağı 1,3 ve 4 . sınıflardır. SDK düzeyinde en çok 1. sınıfların kaygılı olduğu görülmektedir. Ardından ise 2, 3 ve 4 . sinıflar gelmektedir.

Müzik öğretmenliği lisans öğrencilerinin SDK puanlarınınçalgıya göre ANOVA sonuçları Tablo 5.’te verilmiştir.

Tablo 5. SDK Puanlarının Çalgıya Göre ANOVA Sonuçları

\begin{tabular}{|c|c|c|c|c|c|c|c|c|c|}
\hline & \multicolumn{3}{|c|}{$f, \bar{x}$ ve ss Değerleri } & \multicolumn{5}{|c|}{ ANOVA Sonuçları } & \multirow[b]{2}{*}{$\mathrm{p}$} \\
\hline & $\mathrm{N}$ & $\overline{\mathrm{x}}$ & $\operatorname{SS}(\sigma)$ & Var. K. & KT & $\mathrm{Sd}$ & KO & $\mathrm{F}$ & \\
\hline \multicolumn{10}{|l|}{ Sürekli Kayg1 } \\
\hline Keman & 83 & 44,51 & 9,49 & G. Aras1 & 1656,736 & 12 & 138,061 & 1,857 & ,039 \\
\hline Viyola & 27 & 43,22 & 7,11 & G. İçi & 24391,326 & 328 & 74,364 & & \\
\hline Çello & 37 & 45,75 & 6,68 & Toplam & 26048,065 & 340 & & & \\
\hline Kontrbas & 1 & 27,00 & & & & & & & \\
\hline Flüt & 54 & 40,59 & 8,49 & & & & & & \\
\hline Gitar & 49 & 42,87 & 9,48 & & & & & & \\
\hline Bağlama & 34 & 44,70 & 7,81 & & & & & & \\
\hline Piyano & 25 & 47,28 & 8,18 & & & & & & \\
\hline Ud & 11 & 40,45 & 9,13 & & & & & & \\
\hline Şan & 15 & 42,00 & 7,19 & & & & & & \\
\hline Kanun & 3 & 44,00 & 11,26 & & & & & & \\
\hline Klarnet & 1 & 46,00 & . & & & & & & \\
\hline Ney & 1 & 53,00 & & & & & & & \\
\hline
\end{tabular}




\begin{tabular}{cccccccccc}
\hline Durumluk Kayg1 & & & & & & & & \\
Keman & 83 & 46,83 & 11,85 & G. Aras1 & 2106,729 & 12 & 175,561 & 1,397 &, 166 \\
Viyola & 27 & 40,33 & 12,72 & G. İçi & 41228,908 & 328 & 125,698 & & \\
Çello & 37 & 46,37 & 9,61 & Toplam & 43335,636 & 340 & & \\
Kontrbas & 1 & 41,00 &. & & & & & \\
Flüt & 54 & 42,18 & 11,96 & & & & & \\
Gitar & 49 & 43,10 & 9,69 & & & & & \\
Bağlama & 34 & 42,32 & 10,71 & & & & & \\
Piyano & 25 & 43,56 & 9,74 & & & & & \\
Ud & 11 & 38,45 & 11,99 & & & & & \\
Şan & 15 & 41,93 & 13,31 & & & & & \\
Kanun & 3 & 45,33 & 6,65 & & & & & \\
Klarnet & 1 & 32,00 &. & & & & & \\
Ney & 1 & 40,00 &. & & & & & & \\
\hline
\end{tabular}

Analiz sonuçları, müzik öğretmenliği öğrencilerinin sürekli kaygı düzeyi arasında çalgı bakımından anlamlı bir fark olduğunu fakat durumluk kaygı düzeyi arasında anlamlı fark olmadığını göstermektedir. Sürekli Kayg1 $\mathrm{F}_{(12,328)}=1,85, \mathrm{p}<.01$. Durumluk Kayg1 $\mathrm{F}_{(12,328)}=1.39, \mathrm{p}>.01$. Bulgulara göre Sürekli kayg1 düzeyi en çok ve en az olan çalgılar sırasıyla; ney, piyano, klarnet, çello, bağlama, keman, kanun, viyola, gitar, şan, flüt, ud ve kontrbas öğrencileri gelmektedir. Durumluk kaygi düzeyi en çok ve en az olan çalgılar ise sırasıyla; keman, çello, kanun, piyano, gitar, bağlama, flüt, şan, kontrbas, viyola, ney, ud ve klarnet öğrencileri gelmektedir.

Müzik öğretmenliği lisans öğrencilerinin SDK' nın mezun olduğu liseye göre t-testi sonuçları Tablo 6'da gösterilmiştir.

Tablo 6. SDK Puanlarının Mezun Olduğu Liseye Göre T-Testi Sonuçları

\begin{tabular}{ccccccc}
\hline & $\mathrm{N}$ & $\begin{array}{c}\text { Ortalama } \\
(\overline{\mathrm{x}})\end{array}$ & $\begin{array}{c}\text { Standart } \\
\text { Sapma( } \sigma)\end{array}$ & sd & $\mathrm{t}$ & $\mathrm{p}$ \\
\hline Sürekli Kayg1 & & & & & & \\
\hline GSL & 238 & 43,55 & 8,89 & 337 &, 15 &, 875 \\
Alan Dış1 & 101 & 43,72 & 8,49 & & & \\
\hline $\begin{array}{c}\text { Durumluk } \\
\text { Kayg1 }\end{array}$ & & & & & & \\
\hline GSL & 238 & 43,86 & 11,47 & 337 &, 54 &, 588 \\
Alan D1ş1 & 101 & 43,15 & 10,05 & & & \\
\hline
\end{tabular}

Müzik öğretmenliği öğrencilerinin SDK' ları mezun olduğu liseye göre anlamlı bir farkl1l1k göstermemektedir. Sürekli kaygı $\mathrm{t}_{(339)}=.15, \mathrm{p}>.01$. Durumluk kayg $\mathrm{t}_{(339)}=.54, \mathrm{p}>.01$. GSL ve alan dış1 mezun olunan liselerin sürekli-durumluk kaygı düzeylerinin durumunda yapılan bağımsız $t$ testi sonucunda GSL ve alan dışı mezun olanların kaygı düzeylerinin birbirinden farklı olduğu görülmüştür. Sürekli kaygıya göre GSL' den mezun olan öğrencilerin sürekli kaygı düzeyi $(\overline{\mathrm{x}}=43,55)$ alan dışından mezun olan öğrencilere göre $(\overline{\mathrm{x}}=43,72)$ daha düşüktür. Durumluk kaygı $\left(\mathrm{t}_{0,05: 75}=, 54\right)$ ' ya göre GSL' den mezun olan öğrencilerin durumluk kaygı düzeyi $(\bar{x}=43,86)$ alan dışından mezun olan öğrencilere göre $(\bar{x}=43,15)$ daha yüksektir. 
Müzik öğretmenliği lisans öğrencilerinin SDK puanlarının üniversiteye göre ANOVA sonuçları Tablo 7'de verilmiştir.

Tablo 7. SDK Puanlarının Üniversiteye Göre ANOVA Sonuçları

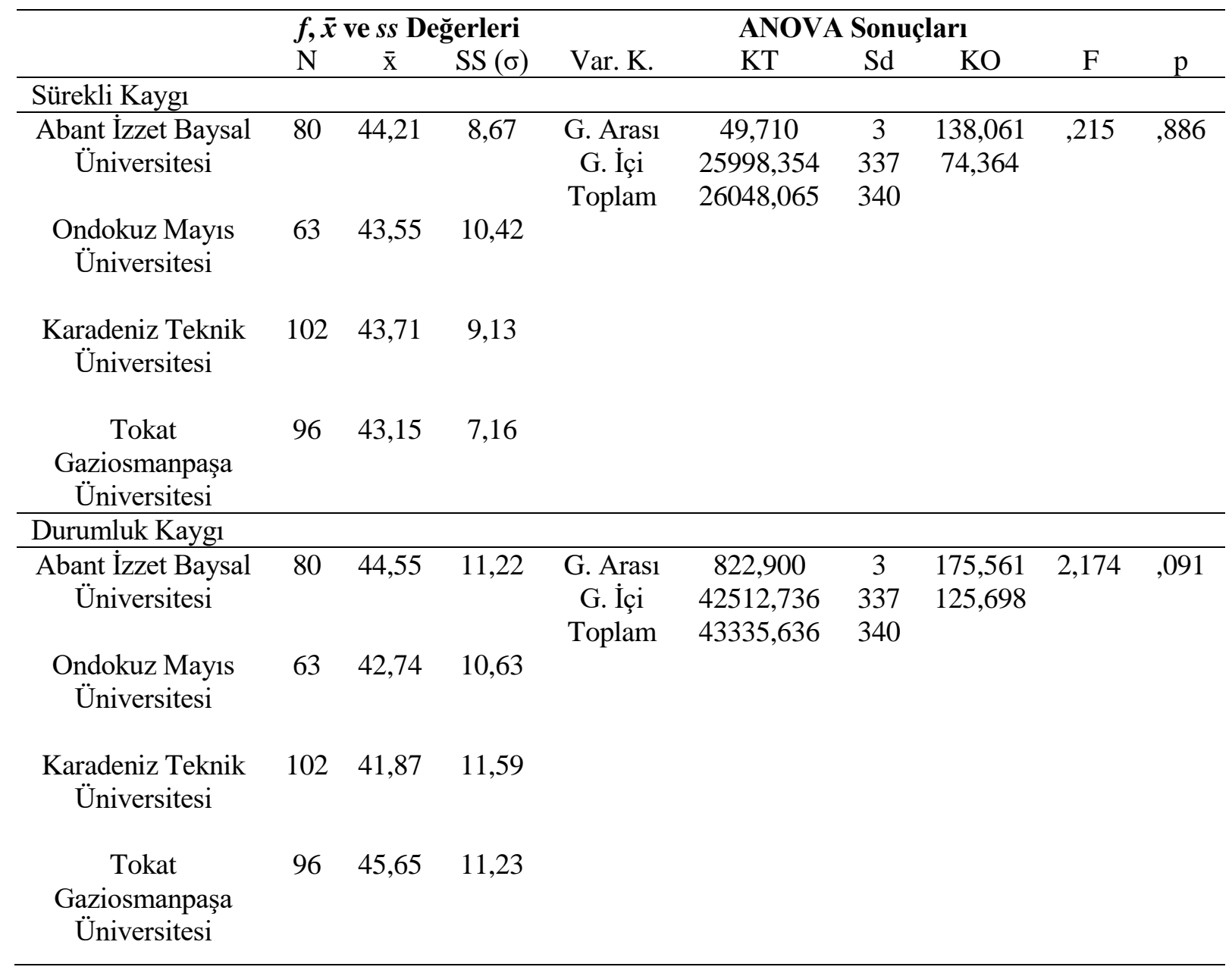

Analiz sonuçları, müzik öğretmenliği öğrencilerinin SDK düzeyi arasında üniversite bakımından her iki durumda da anlamlı bir fark olmadığını göstermektedir. Sürekli Kaygı $F_{(3,337)}=, 215$, p>.01. Durumluk Kayg1 $F_{(3,337)}=2.174, p>$.01. Bulgulara göre sürekli kayg1 puan düzeyinin en yüksekten en küçüğe sıralamasında Abant İzzet Baysal Üniversitesi, Karadeniz Teknik Üniversitesi, Ondokuz Mayıs Üniversitesi ve Tokat Gaziosmanpaşa Üniversitesi gelmektedir. Durumluk kaygıda ise, Tokat Gaziosmanpaşa Üniversitesi, Abant İzzet Baysal Üniversitesi, Ondokuz Mayıs Üniversitesi ve Karadeniz Teknik Üniversitesi gelmektedir.

\section{TARTIŞMA, SONUÇ VE ÖNERILER}

Çalg1 eğitimi almakta olan müzik öğretmenliği lisans öğrencilerinin SDK düzeylerini çeşitli değişkenlere göre tespit etmek amaciyla yapılan araştırmanın bu bölümünde; elde edilen bulgulardan ulaşılan sonuçlar ve bu bulgulara göre geliştirilen öneriler bulunmaktadır.

\section{Tartışma}

Araştırmada cinsiyet değişkenine göre, SDK düzeylerinin kızların erkeklerden anlamlı düzeyde daha yüksek bulunmuştur. SDK düzeyinin cinsiyet değişkenini ele alan çalışmalara bakıldığında Umuzdaş vd. (2019), yapmış oldukları müzik öğretmenliği öğrencilerinin çalgı sınavı performans kaygısını çeşitli değişkenlere göre SDK ve toplam kaygı düzeylerini inceledikleri çalışmada sürekli kaygı durumunda kız öğrencilerin kaygı düzeyleri erkek öğrencilerden daha yüksek olduğu, durumluk kaygıda ise erkek 
öğrencilerin kız öğrencilere göre daha yüksek olduğu görülmektedir.Wesner vd. (1990), müzisyenler arasında performans kaygısının ortaya çıkması konusunu ele aldığı çalışmasında müzik öğrencilerine ve öğretim üyelerine performans kaygısı ile ilgili deneyimlerini ve tutumlarını öğrenmek için yapılan anketin sonucunda kadınların performans kaygısı erkeklere göre daha yüksek çıktığı görülmektedir.Tatar (1997), yapmış olduğu müzisyenlerin kişilik özellikleri, konser kaygıları ve aralarındaki ilişkiyi incelediği çalışmasında durumluk kaygı da kız öğrencilerin kaygı düzeyleri erkek öğrencilere göre daha yüksek olduğunu saptamıştır.Topoğlu (2014)'de müzik öğretmeni adaylarının kişisel özellikleri ile durumluk kaygı düzeyleri arasındaki ilişkiyi incelediği çalışmasında, kız öğrencilerin performans öncesi kaygı düzeylerinin erkek öğrencilere göre anlamlı derecede yüksek olduğu sonucuna ulaşmıştır. Duman'ın (2008) yapmış olduğu çalışmada cinsiyet değişkeninin sınav kaygısı düzeyi üzerinde etkili olduğu görülmektedir. Araştırmadaki bulguların sonuçlarına göre kız öğrencilerin SPK' ları, erkek ögrencilerin kaygılarından fazladır. Patston ve Osborne (2015)'un ergenlerde MPK ve mükemmeliyetçiliği incelediği çalışmasında performans kaygısı konusunda kız öğrencilerin erkek öğrencilere göre önemli oranda daha yüksek puanlar aldığı görülmüştür. 5 çalg1 ve şan alanında profesyonel müzisyenlerle birlikte yürüttüğü çalışmasında Hamann (1982), kadın müzisyenlerin erkek müzisyenlere göre daha fazla performans kaygısı yaşadığı ve buna karşılık kadınların göstermiş olduğu performanslar erkeklere oranla daha iyi olduğu sonuçlanmıştır. Aydın (2017), MPK düzeyi ve duygusal zeka düzeylerin çeşitli değişkenlere göre incelediği çalışmasında kızların MPK' s1, erkeklerin MPK' sından anlamlı bir şekilde daha yüksek olduğu görülmektedir. Baydağ ve Alpagut (2016) müzik eğitiminde sahne-performans kaygısının müzik eğitimi bölümü ve konservatuvar öğrencileri karşılaştırılmasında ise kaygı ile kişilik arasında anlamlı bir ilişki olduğunu ve kızların erkeklere göre daha yüksek düzeyde performans kaygısı duyduğu çıkan sonuçlar arasındadır. Çırakoğlu (2013) ve Nacakcı ve Dalkıran (2011)'da performans kaygısının kişilik özellikleriyle ilişkili olabileceği sonucuna varmıştır. Deniz (1997)'in mesleki müzik eğitimi bölümü öğrencilerinin konser kaygılarını ele aldığı çalışmasında elde ettiği bulgulara göre cinsiyet değişkenine göre anlamlı farklılık saptanmaktadır. Tokinan (2014)' nın müzik öğretmen adaylarının MPK üzerine yapmış olduğu çalışmada da kızların performans kaygısı erkeklere göre yüksek düzeyde olduğu görülmüştür. Iusca ve Dafinoiu (2011) lisans ögrencilerinde performans kaygısı ve düzeyinde cinsiyetin ve enstrümanın etkisine bakmışlar ve performans kaygısı düzeyinin cinsiyete ve müzik aletine göre değiştiği sonucuna ulaşmıştır. Aydın ve İşgörür (2018) ortaokul ve lise düzeyinde öğrenim görmekte olan konservatuvar öğrencilerinin MPK' sını ele aldığında da MPK' larının cinsiyete göre anlamlı farklılık göstermekte olduğunu saptamıştır. Küçük (2010), müzik öğretmenliği bölümü okuyan öğrencilerin SPK, benlik saygısı ve çalgı başarıları arasındaki ilişkiyi ele aldığı çalışmasında öğrencilerin SPK düzeyi üzerinde cinsiyetin herhangi bir etkisinin olmadığı görülmektedir.

Kılıç (2018), ele aldığı çalışmasında öğrencilerin kaygı düzeylerinde cinsiyete göre anlamlı bir fark görülmediğini tespit etmiştir. Yokuş vd. (2013), müzik öğretmeni aday adaylarının cinsiyet değişkeni açısından SDK' sında anlamlı farklılık bulunmadığını saptamıştır. Araştırmalardan elde edilen sonuçlar bu çalışmadan elde edilen sonuçlarla doğru orantı göstermektedir. Buna ek olarak eğitimin farklı alanlarında da bu sonuçları destekleyen pek çok çalışmaya rastlanmaktadır.

Yaş değişkeni incelendiğinde SDK düzeylerinin arasında anlamlı farklılık gösterdiğine ilişkin bulgulara ulaşılmıştır. SDK düzeyinin yaş değişkenini ele alan çalışmalara bakıldığında Tokinan (2014)' in öğretmen adaylarının MPK' ları çalışmasında yaş değişkeninde anlamlı bir fark görülmemiştir. Yokuş vd. (2013) yapmış olduğu çalışmada müzik öğretmeni aday adaylarının yaş değişkeni açısından SDK düzeylerinde anlamlılık bulamamıştır.Wesner (1990), müzisyenler arasında performans kaygısının ortaya çıkması konusunu ele aldığı çalışmasında müzik öğrencilerine ve öğretim üyelerine performans kaygısı ile ilgili deneyimlerini ve tutumlarını öğrenmek için yapılan anketin sonucunda yaş değişkeni performans kaygısını etkilemediği görülmüştür.Elde edilen sonuç bu araştırmacıların yapmış olduğu çalışmayı desteklememektedir.

Sınıf düzeyi değişkenine bakıldığında SDK düzeylerinin arasında anlamlı farklılık vardır. SDK düzeyinin sınıf düzeyini ele alan çalışmalar incelendiğinde Umuzdaş vd. (2019), yapmış oldukları müzik öğretmenliği öğrencilerinin çalgı sınavı performans kaygısını çeşitli değişkenlere göre SDK ve toplam kaygı düzeylerini inceledikleri çalışmada durumluk kaygıda sınıf, çalgı ve akademik başarı puanları 
değişkenleri arasında anlamlı farklılık görülmektedir. Nacakcı ve Dalkıran (2011), öğrencilerin bireysel çalgı sınavına yönelik kaygılarını araştırdığı çalışmasında müzik öğretmenliği bölümü okuyan 2.ve 3 . sinıflar arasında anlamlı bir fark saptamışlardır. 2. sınıflar, 3. sinıflara göre daha fazla kaygı yaşamaktadır. Aydın (2017), konservatuvarda öğrenim görmekte olan ortaokul ve lise bölümü müzik öğrencilerinin MPK düzeyleri ile duygusal zeka seviyelerinin çeşitli değişkenlerle ilişkisini incelediği çalışmadan elde edilen bulgulara göre MPK' nın sınıf değişkeni ile arasında anlamlı farklar olduğu görülmektedir. Edmonson (2012) alt sınıflar ve üst sınıfların müzik eğitimi lisans programları arasındaki MPK düzeylerindeki farklı1ıkları belirlenmesini amaçlayan çalışmasında alt sınıfların MPK' nın üst sınıflara göre daha düşük olduğunu tespit etmiş ve performans kaygısının her seviyedeki müzisyeni etkileyebilecek olduğunu söylemiştir. Patston ve Osborne (2016), 5 ve 12. sinıflar arasındaki mükemmeliyetçiliğin gelişim üzerindeki ilerlemesine ve MPK düzeyini ele aldıkları çalışmalarında, bu mükemmeliyetçilik ve MPK' nın yaşa tabii olarak ve deneyimle beraber arttığı sonucuna ulaşmışlardır. Bununla beraber lisans öğrencilerinde de sınıf düzeyi arttıkça öğrencide mesleki çevre beklentisi ve farkındalık düzeyi de kaygının artışında etkili olabilmektedir. Tokinan (2014)' in öğretmen adaylarının MPK'ları çalışmasında sınıf değişkeninde anlamlı bir fark görülmemiștir. Küçük (2010), müzik öğretmeni adaylarının sınav kaygısı puanları sınıf değişkeni açısından anlamlı bir fark yaratmamıştır. Kılıç (2018), öğrencilerin lisans son sınıf olması piyano sınavlarındaki performans kaygısı düzeylerini önemli ölçüde etkilediği ve gelecek hakkında fazla kaygılandıkları, 1. sınıfların ise daha düşük düzeyde kaygıya sahip olduğu tespit etmiştir.

Çalgı değişkeni incelendiğinde öğrencilerin sürekli kaygı düzeyleri arasında anlamlı bir fark olduğunu fakat durumluk kaygı düzeyi arasında anlamlı fark olmadığı görülmektedir. SDK düzeyinin çalgı değişkenini ele alan çalışmalara göre, Iusca ve Dafinoiu (2011) tarafindan lisans öğrencilerinin performans kaygı düzeyi ve performans düzeylerinde enstrüman ve cinsiyetin etkisine bakılmış ve araştırma sonucunda yaylı çalgı çalmakta olan lisans öğrencilerin kaygı düzeyleri üflemeli çalgı ve piyano çalan öğrencilerden daha fazla olduğunu tespit edilmiştir.

Öğrencilerin mezun olduğu lise değişkenine bakıldığında, SDK düzeyleri arasında anlamlı fark olmadığı görülmektedir. Aydın ve İşgörür (2017) müzik öğrencilerinin MPK' ları çeşitli değişkenlere göre incelediği çalışmasında mezun oldukları okul türünün MPK açısından anlamlı bir fark oluşturmadığı tespit etmiştir. Yokuş vd. (2013) yapmış olduğu çalışmada müzik öğretmeni aday adaylarının mezuniyet değişkeni bakımından SDK' sında anlamlılık saptamamıştır. Sazak ve Ece (2004)' nin çalışmasında, mezun olduğu okul değişkenine göre öğrencilerin kaygı seviyesinde anlamlı bir fark saptamamışlardır.

Küçük (2010), güzel sanatlar lisesi ve alan dışı liseden mezun olan müzik öğretmenliği öğrencilerinin sınav kaygısı puanları arasında anlamlılık bulamamıştır. Tokinan (2014)'ın öğretmen adaylarının müzik performans kaygıları çalışmasında yaş değişkeninde anlamlı bir fark görülmemiştir. Nacakcı ve Dalkıran (2011), müzik eğitimi öğrencilerin bireysel çalgı sınavına yönelik kaygı düzeylerinde mezuniyet değişkenine göre anlamlı bir fark saptamamıştır.

Üniversite değişkeni incelendiğinde öğrencilerin SDK düzeyleri arasında da anlamlı fark olmadığı görülmektedir. Tatar (1997), yapmış olduğu müzisyenlerin kişilik özellikleri, konser kaygılan ve aralarındaki ilişkiyi incelediği çalışmasında okul değiş̧kenine göre durumluk kaygıda anlamlı bir fark saptamakta ve sürekli kaygıda ise böyle bir farklılık görülmemektedir. Deniz (1997)' in mesleki müzik eğitimi bölümü öğrencilerinin konser kaygılarını ele aldığı çalışmasında elde ettiği bulgulara göre okul değişkeni açısından anlamlı farklılık saptamaktadır.

\section{Sonuç ve Öneriler}

Araştırma bulgularına göre müzik öğretmenliği bölümü lisans öğrencilerinin çalgı sınavındaki performans kaygılarından yola çıkılarak, araştırmada elde edilen alt problemler doğrultusunda aşağıdaki sonuçlara ulaşılmıştır.

1. Müzik öğretmenliği lisans öğrencilerinin SDK' sının cinsiyete göre ortalama puanlarına bakıldığında, istatistiksel olarak anlamlı farklılık göstermektedir. SDK' dan alınan puanlara göre farklılık gösterip göstermediğini belirlemek amacıyla yapılan bağımsız t-testi sonucunda kız ve erkek öğrencilerin SDK envanterinden alınan puanlara göre anlamlı bir farklılık olduğu görülmektedir. Sürekli kayg1 
$\mathrm{t}(339)=3.21, \mathrm{p}<.01$. Durumluk kayg1 $\mathrm{t}(339)=3.07, \mathrm{p}<.01$. Yapılan test sonucunda kizların SDK' s1, erkeklerin SDK' sından istatistiksel olarak anlamlı bir şekilde daha yüksek görülmektedir.

2. Müzik öğretmenliği lisans öğrencilerinin SDK' sının yaşa göre farklılaşıp farklılaşmadığını anlamak için yapılan ANOVA testinin her iki kaygı durumu için ortalama puanlarına bakıldığında, analiz sonuçları anlamlı bir fark olduğunu göstermektedir. Sürekli Kaygı $F(3,337)=3.39, p<.01$. Durumluk Kaygı $\mathrm{F}(3,337)=3.64, \mathrm{p}<.01$. Farkın kaynağ $18-21$ ve $22-25$ yaş aralığında olanlardır.

3. Müzik öğretmenliği lisans öğrencilerinin SDK' sının sınıf düzeylerin göre farklılaşıp farklılaşmadığını anlamak için yapılan ANOVA testinin ortalama puanlarına bakıldığında, analiz sonuçları anlamlı bir fark olduğunu göstermektedir. Sürekli Kayg1 $F(3,337)=6,30, p<.01$. Durumluk Kaygı $F(3,337)=6.53, p<.01$. Araştırmada SDK düzeyleri sınıf değişkenine göre 1, 3 ve 4 . sınıf öğrencileri anlamlı bir ilişki vardır. Kaygı düzeyi en çok 1. sınıflarda en düşük ise 4. sınıflarda görülmüştür. Bu nedenle 1. sınıfların ilk defa komisyon tarafından değerlendirilmeleri etki etmiş olduğu düşünülebilir. Fakat her lisans programında öğrenim görmekte olan öğrencilerin kaygı düzeyi aktif rol almaktadır.

4. Müzik öğretmenliği lisans öğrencilerinin SDK'sının çalgıya göre farklılaşıp farklılaşmadığını anlamak için yapılan ANOVA testinin ortalama puanlarına bakıldığında, analiz sonuçları, sürekli kaygı düzeyi arasında sınıf bakımından anlamlı bir fark olduğunu fakat durumluk kaygı düzeyi arasında anlamlı fark olmadığını göstermektedir. Sürekli Kayg1 $F(12,328)=1,85, p<.01$. Durumluk Kayg1 $F(12,328)=1.39$, p>.01. Sürekli kaygı düzeyi en çok ve en az olan çalgılar sırasıyla; ney, piyano, klarnet, çello, bağlama, keman, kanun, viyola, gitar, şan, flüt, ud ve kontrbas öğrencileri gelmektedir. Durumluk kaygı düzeyi en çok ve en az olan çalgılar ise sırasıyla; keman, çello, kanun, piyano, gitar, bağlama, flüt, şan, kontrbas, viyola, ney, ud ve klarnet öğrencileri gelmektedir.

5. Müzik öğretmenliği lisans öğrencilerinin SDK' sının mezun olduğu liseye göre farklılaşıp farklılaşmadığını anlamak için yapılan bağımsız t-testinin ortalama puanlarına bakıldığında, anlamlı bir farkl11ı göstermemektedir. Sürekli kaygı $\mathrm{t}(339)=.15, \mathrm{p}>.01$. Durumluk kaygı $\mathrm{t}(339)=.54, \mathrm{p}>.01$. Sürekli kaygı'ya göre GSL' den mezun olan öğrencilerin sürekli kaygı düzeyi $\neg(\overline{\mathrm{x}}=43,55)$ alan dışından mezun olan öğrencilere göre $(\bar{x}=43,72)$ daha düşük olduğu görülmektedir. Durumluk kaygı'ya göre GSL' den mezun olan öğrencilerin durumluk kaygı düzeyi $\neg(\overline{\mathrm{x}}=43,86)$ alan dışından mezun olan öğrencilere göre $(\bar{x}=43,15)$ daha yüksek olduğu görülmektedir.

6. Müzik öğretmenliği lisans öğrencilerinin SDK' sının üniversiteye göre farklılaşıp farklılaşmadığını anlamak için yapılan ANOVA testinin ortalama puanlarına bakıldığında, analiz sonuçları her iki durumda da anlamlı bir fark olmadığını göstermektedir. Sürekli Kaygı $F(3,337)=, 215, p>.01$. Durumluk Kayg1 $F(3,337)=2.174, p>.01$. Bulgulara göre sürekli kaygı puan düzeyinin en yüksekten en küçüğe sıralamasında Abant İzzet Baysal Üniversitesi, Karadeniz Teknik Üniversitesi, Ondokuz May1s Üniversitesi ve Tokat Gaziosmanpaşa Üniversitesi gelmektedir. Durumluk kaygıda ise, Tokat Gaziosmanpaşa Üniversitesi, Abant İzzet Baysal Üniversitesi, Ondokuz Mayıs Üniversitesi ve Karadeniz Teknik Üniversitesi gelmektedir.

Bu sonuçlardan yola çıkılarak, SDK' nın ya da MPK' nın birden fazla çalışmada değinildiği gibi kızların erkeklere göre çok daha yüksek olduğu saptanmıștır. Literatür incelenebildiği kadarıyla bu durumu neden-sonuç ilişkisiyle ele alan bir çalışma görülmemektedir. Dolayısıyla kızların erkeklere göre neden daha çok kaygılandığı ve bunu en aza indirgeme ile ilgili çalışmalar yapılması önerilebilir.Müzik öğrencilerinin çalgı sınavında ya da konserinde performansını gösterdiği alandaki müzikal ve teknik beceriyi sergilemenin yanında, yaşamış oldukları kaygı düzeylerini de kontrol edebilmelerine ilişkin ilgili çalışmalara yön verilebilir. Dolayısıyla bir müzisyenin öğrencilik yaşamı boyunca branşıyla alakalı müzikal gelişime ve tekniksel beceriye gösterilen önem kadar, öğrencinin performans kaygısını yönetmesine dair bilinçli bir yaklaşıma da önem verilebilir ve MPK yaşayan öğrencilerin, durumluk kaygı düzeylerinin en aza indirgenmesinde yardımcı olunabilir.Kaygıyı en aza indirgeme için tedavi yöntemleri bulunmaktadır. Bu yöntemler arasında psikolojik, fiziksel ya da mental ve zihinsel teknikler bulunmaktadır. Kaygının bu gibi tekniklerle azalıp azalmadığını inceleyen deneysel çalışmalara rastlanmamıştır. Bu konu ileriki çalışmalar için incelenmeye alınabilir. 
Bilgilendirme / Acknowledgement:

1- Araştırmacıların katkı oranı eşittir.

2-Bu çalışma Tokat Gaizosmanpaşa Üniversitesi Sosyal Bilimler Enstitüsü’nde Doç. Dr. Mehmet Serkan UMUZDAŞ danışmanlığında Hatice TÖK tarafından hazırlanan "Müzik Öğretmenliği Lisans Öğrencilerinin Çalgı Sınavındaki Performans Kaygı Düzeylerinin Çeşitli Değişkenlere Göre İncelenmesi” isimli yüksek lisans tezinden üretilmiş̧ir.

3- Makalenin verileri 2019 yılında toplanmış ve yorumlanmıştır.

4- Makalenin yazarları arasında çıkar çatışması bulunmamaktadır.

5- Bu makalede araştırma ve yayın etiğine uyulmuştur.

\section{KAYNAKÇA}

Alptekin, A. G. (2012). Müzik performans anksiyetesi. Trakya Üniversitesi Sosyal Bilimler Dergisi, 14(1), 137-148.

Aydın, B. (2017). Konservatuvarda ortaokul ve lise düzeyinde ögrenim gören müzik öğrencilerinin müzik performans kaygı düzeyleri ile duygusal zeka düzeylerinin çeşitli değişkenlere göre incelenmesi. Yayınlanmamış Doktora Tezi, Dokuz Eylül Üniversitesi Eğitim Bilimleri Enstitüsü, İzmir.

Aydın, B. ve İşgörür, Ü. (2018). Ortaokul ve lise düzeyinde öğrenim gören konservatuvar öğrencilerinin müzikperformans kaygılarının çeşitli değişkenlere göre incelenmesi. Afyon Kocatepe Üniversitesi Akademik Müzik Araştırmaları Dergisi (AMADER), 4(7), 1-20.

Baydağ, C. ve Alpagut, U. (2016). Müzik eğitimi bölümü ve konservatuvar öğrencilerinin sahne/performans kaygısı açısından karşılaştırılması (Pilot Çalışma). Uluslararası Sosyal Araştırmalar Dergisi, 9(44), 857-864.

Büyüköztürk, D. (1997). Araştırmaya yönelik kaygı ölçeğinin geliştirilmesi. Kuram ve Uygulamada Ĕ̈itim Yönetimi Dergisi, 12(12), 453-464.

Cox, W. J. B. ve Kenardy, J. (1993). Performance anxiety, social phobia, and setting effects in instrumental music students. Journal of Anxiety Disorders, 7(1), 49-60.

Çırakoğlu, O. C. (2013). Sahnedeki düşman: müzisyenlerde performans kaygısı üzerine bir gözden geçirme. Türk Psikoloji Yazıları, 16(32), 95-104.

Deniz, J. (1997). Mesleki müzik eğitimi öğrencilerinin konser kaygılarının cinsiyet, kişilik ve okul değişkenleri açısından incelenmesi. M. Ü. Atatürk Eğitim Fakültesi Eğitim Bilimleri Dergisi, 10, 75-82.

Duman, G.K. (2008). İlköğretim 8.sınıf ögrencilerinin durumluk sürekli kaygı düzeyleri ile sınav kaygısı düzeyleri ve ana-baba tutumları arasındaki ilişkinin incelenmesi. Yayınlanmamış yüksek lisans tezi, Dokuz Eylül Üniversitesi Eğitim Bilimleri Enstitüsü Eğitim Bilimleri Anabilim Dalı, İzmir.

Edmonson, J. M. (2012). Differences in music performance anxiety levels between underclassmen and upperclassmen music education undergraduates. Texas Music Education Research, 15-19.

Hamann, D.L. (1982). An assessment of anxiety in instrumental and vocal performances. Journal of Research in Music Education, 30(2), 77-90.

Iusca, D. andDafinoiu, I. (2011). Performance anxiety and musical level of undergraduatestudents in exam situations: the role of gender and musical instrument. Procedia-Social and Behavioral Sciences, 33, 448-452.

Kılıç, D. B. Ç. (2018). An Investigation of Music Teacher Candidates Performance Anxiety Levels in Piano Examinations. Journal of Education and Learning, 7(1), 299-308.

Küçük, D. P. (2010). Müzik öğretmeni adaylarının sınav kaygısı, benlik saygısı ve çalgı başarıları arasındaki ilişkinin incelenmesi. Ahi Evran Üniversitesi Ĕgitim Fakültesi Dergisi, 11(3), 37-50. 
Nacakcı, Z. ve Dalkıran, E. (2011). Müzik eğitimi anabilim dalı öğrencilerinin bireysel çalgı sınavına yönelik kaygıları. Mehmet Akif Ersoy Üniversitesi Sosyal Bilimler Enstitüsü Dergisi, 3(5), 46-56.

Öner. N. and Le Compte A. (1983). Concurrent validity and reliability ofstate-trait anxiety Inventory in Turkish population. İstanbul: Boğazici University Press.

Öner, N. and Le Compte, A. (1985). Durumluk-sürekli kaygı envanteri el kitabı. İstanbul: Boğaziçi Üniversitesi Yayınları.

Patston, T. andOsborne M. (2015). The developmental features of music performance anxiety and perfectionism in school age music students. Performance Enhancement \& Health, 4(1-2), 42-49.

Sazak, N. ve Ece A.S. (2004). Bolu Anadolu güzel sanatlar lisesi öğrencilerinin ÖSS ve özel yetenek sınavlarına yönelik kaygıları. 1924 - 2004 Musiki Muallim Mektebinden Günümüze Müzik Öğretmeni Yetiştirme Sempozyumu, Süleyman Demirel Üniversitesi, Isparta.

Spielberger, C. D. and Weitz, H. (1964). Improving the academic performance of anxious college freshmen: A group-counseling approach to the prevention of underachievement. Psychological Monographs: General and Applied, 78(13), 1-20.

Spielberger, C. D., Gorsuch, R. L. and Lushene, R. E. (1970). Manual for the state-trait anxiety inventory. Palo Alto, CA: Consulting Psychologists Press.

Tatar, J. (1997). Müzisyenlerin kişilik özellikleri, konser kaygılan ve aralarındaki ilişkinin incelenmesi. Yayınlanmamış Doktora Tezi, Marmara Üniversitesi Fen Bilimleri Enstitüsü, İstanbul.

Tokinan, B. Ö. (2013) Kenny müzik performans kaygısı envanterini Türkçe’ye uyarlama çalışması. Ahi Evran Üniversitesi Kirşehir Eğitim Fakültesi Dergisi, 14(1), 56-65.

Tokinan, B. (2014). Öğretmen adaylarının performans kaygılarının bireysel özellikler bakımından incelenmesi. NWSA-Fine Arts, 9(2), 84-100.

Topoğlu, O. (2014) Musical performance anxiety: relations between personal features and state anxiety levels of pre-service music teachers. International Online Journal of Educational Sciences, 6(2), 337-348.

Umuzdaş, M. S., Tök, H. and Umuzdaş, S. (2019). An examination of the performance anxiety levels of undergraduate music teaching students in the instrument exams according to various variables ("Case of Tokat Province"). International Journal of Higher Education, 8(4), 221-230.

Üldaş, İ. (2005). Öğretmen ve ögretmen adaylarına yönelik matematik kaygı ölçeği (MKÖ-Ö)'nin geliş̧irilmesi ve matematik kaygısına iliş̧kin bir değerlendirme. Yayınlanmamış yüksek lisans tezi, Marmara Üniversitesi Eğitim Bilimleri Enstitüsü, İstanbul.

Wesner, R. B., Noyes, R. Jr. and Davis, T. L. (1990). The occurence of performance anxiety among musicians. Journal of Affective Disorders, 18(3), 177-185.

Yokuş, T., Yokuş, H. ve Kalaycıoğlu, Ş. G. (2013). Müzik öğretmeni aday adaylarının sürekli-durumluk kaygı düzeyleri ve müzik özel yetenek sınavı başarıları arasındaki ilişkinin incelenmesi. $E$ Journal of New World Sciences Academy, 8(1), 153-163. 